\title{
STANLEY HARDING BOGGS
}

$1914-1991$

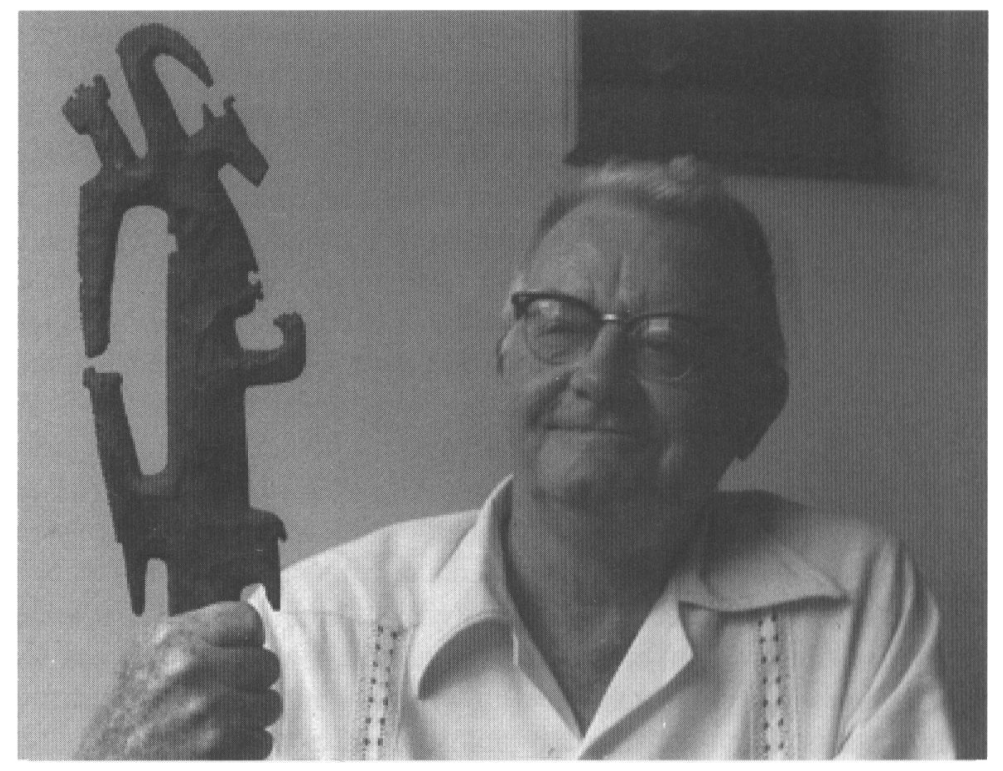

tanley Harding Boggs, head of the Department of Archaeology of the Office of Cultural $\mathrm{S}$ Patrimony of El Salvador, died suddenly of a stroke on December 30,1991, at the age of 77 . He is survived by his daughter, Mary Elizabeth Boggs de Cornejo, and several grandchildren.

Stan was actively involved in the archaeology of his adopted country until the very end of his life, planning new investigations, remaining in contact with colleagues by travel and correspondence, and opening his home, as always, to archaeologists and other scholars with an interest in El Salvador. For nearly 50 years he was the resident archaeologist in El Salvador, and he was directly or indirectly responsible for much of the research and almost all of the protection and conservation of the country's archaeological sites accomplished during these years.

Stan was born on August 8, 1914, in Warsaw, Indiana, the son of Stanley S. and Mary H. Boggs, and spent his childhood on his parents' large farm. He graduated with a bachelor's degree from Northwestern University in 1935 and received a master's in anthropology from the University of Arizona the following year. He pursued graduate studies at Harvard from 1937 until 1940. His early archaeological field experience included work at Kinishba, Arizona, in 1936; at the Nevin and Richards shell heaps in Blue Hill, Maine, in 1937-1938; and in northern Haiti, where he worked with Froelich Rainey in 1939 investigating a potential landfall of Columbus. In 1939 he accompanied John M. Longyear on the Carnegie Institution of Washington project at Cópan, Honduras, where he assisted

American Antiquity, 61(1), 1996, pp. 57-61.

Copyright $C$ by the Society for American Archaeology 
Gustav Strömsvik and Tatiana Proskouriakoff with the excavation and repair of the south side of Structure 10L-11, the largest building at that southeastern Maya site.

Stan first went to El Salvador in October 1940, recommended by A. V. Kidder as field director of John M. Dimick's second season of excavations at the large site of Campana San Andrés, in the western part of the country. Immediately after the end of this work, he was again asked by Kidder to be Longyear's assistant for an Andean Institute excavation and survey project in El Salvador. In 1941 and early 1942 Longyear surveyed a number of sites and excavated at Los Llanitos near San Miguel. Before Longyear arrived, however, Stan was involved in an automobile accident and was incarcerated in Santa Tecla until his trial and release in spring 1942.

Later in 1942 Stan excavated at Tazumal, the Classic and Early Postclassic site at Chalchuapa that was the focus of much of his attention in later years. He surveyed and reported on a number of sites and began the systematic recording of private collections of pottery and other artifacts that continued throughout his life. Boggs and Longyear's 1941 and 1942 work was published in a Peabody Museum Memoir.

In November 1942 Stan married Inés Sagrera Rosales, of San Salvador, making El Salvador his home. From 1943 to 1945 the government funded additional work at Tazumal. He was becoming increasingly involved with the National Museum and other government programs. In 1946 and 1947 he and his wife joined John Dimick's United Fruit Company excavations at Zaculeu, in the western Guatemala highlands, working with Gus Strömsvik and Aubrey Trik. In 1947 he was replaced by Richard Woodbury and returned to an expanded program of research at Tazumal from 1948 to 1950 , with limited excavations in the three following years. He supervised construction of a new museum at Tazumal in 1950 and 1951.

Stan retained an affiliation with the Carnegie Institution of Washington until 1948 when he accepted the position as head of the Department of Archaeological Excavations in El Salvador's Ministry of Popular Culture, remaining there until 1954.

As uncomfortable situation in El Salvador involving a jealous bureaucrat, who in 1954 falsely accused Stan of shipping treasures out of the country, led him to return to Indiana for several years. In 1961 Stan moved to Cambridge, Massachusetts, to write a monograph on his work at Tazumal, supported in part by two grants from the American Philosophical Society.

At the death of his wife, Stan returned to San Salvador with his 15-year-old daughter in 1963 (he married again in 1968, but his wife, Berta Sagrera Rosales, who had been his sister-in-law, predeceased him in 1987). He joined the faculty of the University of El Salvador as head of the archaeology department, teaching there for five years. Two years later, in 1965, he also accepted an offer to head the archaeology department at the National Museum, later within the Office of Cultural Patrimony, and he remained in this position until 1988, despite increasingly severe eye problems. From 1988 until his death he directed the archaeological registry at the National Museum.

In the years after his return to El Salvador, Stan supervised, generally oversaw, or helped arrange excavations at sites all over the country. He worked and helped others at Cihuatán, an important Early Postclassic site north of San Salvador, into the 1980s. In 1977 he returned to San Andrés, where he had started 37 years earlier, and excavated Structure 7. A dam planned for the middle Lempa River drainage necessitated the Cerrón Grande Project, an extensive river basin survey and excavation effort enlisting Salvadoran and North American archaeologists. He began the excavations of the Late Preclassic potbelly boulder figures at Santa Leticia; excavated the extensive deposit of Middle Preclassic figurines at Finca Bolinas; undertook and oversaw the investigation of the huge shell heap at Asanyamba, on the Gulf of Fonseca; conducted major salvage efforts in the San Lorenzo dam area; and started new work at the important early site of Cara Sucia in far western El Salvador. In the late 1970s political unrest made work in some areas difficult, and the civil war that engulfed the country in the 1980s brought archaeology in most areas to a standstill. In 1986 he wrote that no foreign group had tried to work in El Salvador since 1980, and his budget, always small, dwindled further.

Stan did not complete a detailed report on his excavations at Tazumal, although he wrote several summary reports that indicate the wealth of information he had recovered. His work at Tazumal, San 
Andrés, and many other sites of different ages outlined the archaeological sequence for much of the country, but he did not attempt a general synthesis of the archaeology of E1 Salvador. He preferred to write about artifacts or artifact types that were of special significance to him. His most important studies of this type are those of wheeled figurines, musical instruments, and Middle Preclassic figurines and their clothing. He created an enormous archive of notes and photographs on file cards of artifacts from El Salvador, mostly pottery, which many scholars have found useful.

In the 1970s Stan helped rejuvenate the museum publication program, printing many new studies in archaeology, ethnology, and history, and reprinting many others unavailable in Spanish or out of print. At the end of 1977 he wrote that more had been published that year than in the previous 30 !

In the early 1970s Stan embarked on what became one of his most important successes: convincing the government of El Salvador to declare many of the country's most important sites National Archaeological Monuments. In 1976 alone he noted that six new sites were designated National Monuments. Many of these sites are now owned by the government and are permanently protected by the Office of Cultural Patrimony.

Another of Stan Boggs's great contributions to the archaeology of El Salvador lay in helping others to do research, beginning with Wolfgang Haberland at sites in several parts of the country, Robert Sharer at Chalchuapa, and the author at Quelepa. Others who were able to rely on his assistance or advice before the civil war include Luis Casasola at Jayaque; Manuel López at Casa Blanca, Chalchuapa; William Fowler, Howard Earnest, and Richard Crane at Cerrón Grande; Arthur Demarest at Santa Leticia; William Fowler, Jane Kelley, Karen Bruhns, Gloria Hernández, Margarita Solís, and Zuleyma Menéndez at Cihuatán; Richard Crane at San Andrés; Enrique and Ana María de Martínez at San Lorenzo; Hamed Posada at Asanyamba; Tony Andrews on his survey of salt-production sites; and Payson Sheets and his coworkers in the Zapotitán Valley and at Cerén.

Stan administered or ran interference for much of this research, sometimes without the archaeologist even knowing how much he or she was being assisted. If one thanked Stan directly, he was as likely as not to mumble something unintelligible into his pipe. He was a warm and generous person who cared much for his friends and colleagues, and it is difficult and sad for those of us who knew and treasured him to imagine the archaeology of El Salvador without him there helping.

E. WYLLYS ANDREWS V

Acknowledgments. 1 am grateful to Anthony P. Andrews, Patricia A. Andrews, Rafael Cobos Palma, Hester A. Davis, Wolfgang Haberland, John M. Longyear III, Joyce Marcus, Robert J. Sharer, Payson D. Sheets, Edwin M. Shook, Tomás Vilanova M., Gordon R. Willey, Daniel Wolfman, and Richard B. Woodbury for their recollections and thoughts about Boggs's career and for bibliographic assistance. I have used Boggs's own notes, written for friends and colleagues and printed annually from 1942 to 1989 in The Teocentli, edited first by Carl Guthe and later by Hester Davis and Charles McGimsey. Three obituaries of Boggs were published in 1992: by Wolfgang Haberland in Mesoamerica 23:221-224 and Mexicon 14(4):70-71 and by Rafael Cobos P. in Cuadernos de Arquitectura Mesoamericana, no. 20, p. 96. Additional information on Boggs's research may be found in Síntesis de la arqueología de El Salvador (1850-1991), by Rafael Cobos P. (Cuadernos de Arquitectura Mesoamericana, no. 20, pp. 3-30).

\section{Bibliography of Stanley H. Boggs}

1942 El reconocimiento arqueológico en El Salvador occidental. La Prensa Gráfica, May 23. San Salvador.

1943 Notas sobre las excavaciones en la Hacienda "San Andrés," Departamento de La Libertad. Tzunpame 3(1):104-126. Museo Nacional de El Salvador, San Salvador.

Observaciones respecto a la importancia de "Tazumal" en la prehistoria salvadoreña. Tzunpame 3(1):127-133. Museo Nacional de El Salvador, San Salvador.
Tazumal en la arqueología salvadoreña. Suplemento de la Revista del Ministerio de Instrucción Pública No. 7:1-23. San Salvador.

1944 Excavations in Central and Western El Salvador. Appendix $\mathrm{C}$ in Archaeological Investigations in El Salvador, by J. M. Longyear III, pp. 53-72. Memoirs of the Peabody Museum of Archaeology and Ethnology Vol. 9, No. 2. Harvard University, Cambridge, Massachusetts.

A Human-Effigy Pottery Figure from Chalchuapa, El Salvador. Notes on Middle 
American Archaeology and Ethnology, No. 31, pp. 1-7. Division of Historical Research, Carnegie Institution of Washington, Cambridge, Massachusetts.

A Preconquest Tomb on the Cerro del Zapote, El Salvador. Notes on Middle American Archaeology and Ethnology, No. 31, pp. 8-15. Division of Historical Research, Carnegie Institution of Washington, Cambridge, Massachusetts.

1945 Archaeological Material from the Club Internacional, El Salvador. Notes on Middle American Archaeology and Ethnology, No. 60 , pp. 238-250. Division of Historical Research, Carnegie Institution of Washington, C'ambridge, Massachusetts.

Comentarios sobre una estatua de barro hallada en la zona arqueológica de Chalchuapa. (Translation of A Human-Effigy Pottery Figure from Chalchuapa, El Salvador, 1944.) Tzunpame 5(4):26-32. Museo Nacional de El Salvador, San Salvador.

Informe sobre la tercera temporada de excavaciones en las ruinas de "Tatzumal." Tzunpame 5(4):33-45. Museo Nacional de El Salvador, San Salvador.

Tumba pre-colombina en el Cerro del Zapote, El Salvador. (Translation of a Preconquest Tomb on the Cerro del Zapote, El Salvador, 1944.) Tzunpame 5(4):18-23. Museo Nacional de El Salvador, San Salvador.

1946 Guia de las ruinas de Zaculeu, Departamento de Huehuetenango, Guatemala. Restauración por la United Fruit Company. 20 pp. Castañeda Avila, Guatemala. (Also published as Guide to the Ruins of Zaculeu, 1946?, Richmond, Virginia.)

1947 Bibliografías de antropólogos. Stanley $H$. Boggs. Boletin bibliográfico de antropología americana Vol. 9:322-323 (1946). Instituto Panamericano de Geografía e Historia, México, D.F.

1949 Tlaloc Incensarios in the Baratta Collection, El Salvador. Notes on Middle American Archaeology and Ethnology, No. 94, pp. 36-45. Division of Historical Research, Carnegie Institution of Washington, Cambridge, Massachusetts.

1950 Archeological Investigations in El Salvador. In For the Dean: Essays in Anthropology in Honor of Byron S. Cummings on his 89th Birthday, edited by E. K. Reed and D. S. King, pp. 259-276. Hohokam Museums Association and Southwestern Monuments Association, Santa Fe and Tucson.

"Olmec" Pictographs in the Las Victorias Group, Chalchuapa Archaeological Zone, EI Salvador. Notes on Middle American
Archaeology and Ethnology, No. 99, pp. 85-92. Division of Historical Research, Carnegie Institution of Washington, Cambridge, Massachusetts.

1962 Excavations at Tazumal, El Salvador. Year Book of the American Philosophical Society, 1962:488-491. Philadelphia.

1963 Apuntes sobre varios objetos de barro procedentes de "Los Guapotes", en el Lago de Güija. Antropologia e Historia de Guatemala 15(1):15-21. Reprinted in 1977 as Colección Antropologia e Historia No. 9. Administración del Patrimonio Cultural, San Salvador.

Excavations at Tazumal, El Salvador. Year Book of the American Philosophical Society, 1963:505-507. Philadelphia.

1966 Pottery Jars from the Loma del Tacuazin, El Salvador. Middle American Research Records, Vol. 3, No. 5, pp. 175-185. Publication No. 28 (1967). Middle American Research Institute, Tulane University, New Orleans.

1967 Excavations at Almulunga, El Salvador. Katunob 6(2):57.

An African Art Object in Apparently Early Archaeological Context in El Salvador: A Caveat to the Diffusionist (with E. W. Andrews IV). Ethnos 32:18-25.

1969 Some Boulder Sculptures from Santa Leticia, El Salvador. Katunob 7(1):50.

1971 An Olmec Mask-Pendant from Ahuachapan, E1 Salvador. Archaeology 24:356-358.

1972 Cerámica clásica del barrio Santa Anita, San Salvador, en la colección "Orlando de Sola." Anales del Museo Nacional "David J. Guzmán” 11(37-41):39-48. San Salvador.

Preclassic Underground Ovens of Usulutan, E1 Salvador. Paper presented at the 37 th Annual Meeting of the Society for American Archaeology, Bal Harbour, Florida. Manuscript on file, Middle American Research Institute, Tulane University, New Orleans.

1973 Figurillas con ruedas de Cihuatán y el oriente de El Salvador. Revista Cultura del Ministerio de Educación 59:36-74. San Salvador. (Also published separately as Colección Antropologia No. 3, 1972. Dirección de Cultura, San Salvador.)

Pre-Maya Costumes and Coiffures. Vestimentas y tocados anteriores a los mayas. Américas 25(2):19-24. Reprinted in 1977 as Vestimentas $\mathrm{y}$ tocados anteriores a los mayas. Ancient Costumes and Coiffures. Colección Antropología e Historia No. 8. Administración del Patrimonio Cultural, San Salvador.

Salvadoran Varieties of Wheeled Figurines. (Translation of Figurillas con ruedas de 
Cihuatán y el oriente de El Salvador, 1973.) Contributions to Mesoamerican Anthropology Publication 1. Institute of Maya Studies, Museum of Science, Miami.

1974 Notes on Pre-Columbian Wind Instruments from El Salvador. Baessler-Archiv 22 (n.s.):23-71.

Panorama cultural pre-colombino. Catalog of an exhibition, 15 pp. Museo Nacional "David J. Guzmán," San Salvador.

1975 Radiocarbon Dating of Pot Belly Statuary of El Salvador and Guatemala (with H. H. Cadwell). Manuscript on file, Middle American Research Institute, Tulane University, New Orleans.

1976 Antigüedades salvadoreñas errantes. 1. Dos Xipe Totecs del Lago de Güija. Anales del Museo Nacional "David J. Guzmán" No. 49:107-116. San Salvador.

Las esculturas espigadas y otros datos sobre las ruinas de Cara Sucia, Departamento de Ahuachapán. Anales del Museo Nacional "David J. Guzmán" Nos. 42-48 (1968-1975):37-55. San Salvador.

Hallazgos recientes de figurillas con ruedas de El Salvador. Anales del Museo Nacional "David J. Guzmán" Nos. 42-48 (1968-1975):29-35. San Salvador.

1977 Antigüedades salvadoreñas errantes. 2. Vaso de celebrantes mayas. Anales del Museo Nacional "David J. Guzmán" No. 50:99-102. San Salvador.

1979 Current Archaeological Research in El Salvador. Mexicon 1:43-44.

1980 Incensarios del dios Tlaloc pertenecientes a la colección Baratta, El Salvador. (Translation of Tlaloc Incensarios in the Baratta Collection, El Salvador, 1949.) Colección Antropología e Historia No. 18. Administración del Patrimonio Cultural, San Salvador.
1981 Continuing Archaeological Work in El Salvador. Mexicon 3:61.

1982 A Jadeite and Pyrite Discoidal Ornament from El Salvador. Mexicon 4:64.

1983 Hornos precolombinos en Usulután. Estudios Centroamericanos (ECA) Año 38:769-775. Universidad Centroamericana José Simeón Canas, San Salvador.

A Pottery Cayuco Model from El Salvador. Ethnos 48:205-209.

1985 Comments on Bálsamo and Other Little-known Sculptures of Western Salvador. Manuscript on file, Department of New World Archaeology, Royal Ontario Museum, Toronto. Submitted for publication in Reconstructing the Past: Recent Studies in Mesoamerican and Central American Prehistory, edited by D. M. Pendergast and A. P. Andrews. University of New Mexico Press, Albuquerque.

1990 Apuntes sobre instrumentos de viento precolombinos de El Salvador. (Translation of Notes on Pre-Columbian Wind Instruments from El Salvador, 1974.) Colección Antropología e Historia No. 19. Dirección del Patrimonio Cultural, San Salvador.

1991 Antigüedades salvadoreñas errantes: un jugador de pelota precolombino del área de Izalco. Mesoamérica 21:105-110.

Una extraña figurilla articulada de cerámica. Mesoamérica 21:111-114.

\section{Note}

The lead photograph of Stanley H. Boggs was taken in the National Museum in San Salvador by Tomás Vilanova $M$. in 1977. Boggs is holding an eccentric flint from Structure 7 at San Andrés, recovered during his last excavations there in 1977. Black-and-white internegative and print by Ruth W. Andrews. 